\title{
AN EMPIRICAL ANALYSIS OF ONLINE SHOPPING BEHAVIOR IN INDIA: A DEMOGRAPHIC PERSPECTIVE
}

\author{
Sonia Bhatt \\ Guest Lecturer \\ Madan Mohan Malaviya University of Technology, \\ Uttar Pradesh, India \\ E-mail:sbgod28@gmail.com
}

\begin{abstract}
The e-commerce market of the world is growing at a very fast rate. High internet access rate, increased smart-phone users' rate, growing mobile internet users' rate, reduced smart-phone cost and added internet speed has enabled online shopping too much user-friendly and easier in recent years. The purpose of this paper is to investigate the role of demographic variables of the customers in affecting online shopping behavior. With the help of an extensive literature review, hypotheses were formulated for seven demographic variables i.e. age, gender, marital status, location, level of education, income per month and occupation. With the help of a survey method 542 responses were collected from three different locations New Delhi, Gorakhpur and Mumbai. A chi-square test was performed for checking the association between demographic variables and attitude of online shoppers towards online shopping. A significant positive association was observed between level of education and level of income with the online shopping behavior of the consumers. Based on the empirical findings, this paper includes managerial suggestions for stimulating online shopping behavior among consumers.
\end{abstract}

Keywords: online shopping, online shopping behavior, demographics, E-shopping behavior

ARTICLE INFO

Article History:

Received: 29 July 2019

Accepted: 4 November 2019

Published: 31 December 2019 


\section{INTRODUCTION}

The e-commerce market in India has a great potential especially for online shopping. The internet has changed the way of doing business and now, a traditional mode of shopping has become outdated. Increased internet penetration and cheap smart phones give the potential for growth of online shopping in India. Revenue from the e-commerce sector is expected to increase from US\$39 billion in 2017 to US \$ 120 billion in 2020 growing at a 51\% annual rate (India Brand Equity Foundation [IBEF], July 2019). Internet user base was 121 million in 2011, about 137 million in 2012, 213 million in 2013, 243 million in 2014 and 432 million in 2015 (IAMAI \& IMRB, 2011, 2016) and internet users are expected to increase from 604.21 million as of December 2018 to 829 million by 2021 (India Brand Equity Foundation [IBEF], July 2019). The Indian e-commerce industry have been witnessing an upward growth trend in the market. The Indian e-commerce market is expected to grow four folds to Rs. 10, 48,350 crores by 2022; this growth is supported by increased internet users in India (India Brand Equity Foundation, September 2019). A potential growth of online shopping creates the interest for understanding the impact of the final decision for online shopping (Glassberg, Grover \& Teng, 2006; Liao $\&$ Cheung, 2001). The tremendous growth of online shopping in India creates the interest in understanding what impact consumers' decision to participate in or refrain from shopping online (Zahedi \& Song, 2009). There are various demographic variables of customers which are affecting the online shopping behavior of the consumers. In this study, gender, age, marital status, income, level of education and location were considered as demographic variables. Chen et al. (2005) integrated customer behavioral variables, demographic variables and a transaction database to establish a method for mining changes in customer behavior. Various researchers have pointed out the influence of demographic variables on customers' preference for online store visits (Phang et al., 2010) and various web shoppers/ non shoppers (Karayanni, 2003). E-commerce firms have to take consideration of demographic variables of the consumers so that these firms can understand the online shopping behavior of the consumers in total.

This study aims to determine the association of demographic variables of the customers such as gender, age, marital status, income, occupation, location, and level of education with attitude towards online buying, 


\section{LITERATURE REVIEW}

Online shopping behavior is defined as the most appropriate behavioral appearances of online customers and explores product information (Petrovic Dejan, 2007). The study of the human population is known as demographic. Demographic includes personal information that consists of information on gender, income, education, location, and age. In business, for marketing the product, it is essential to understand the role of the demographic variables of the consumers and by considering these variables, marketing strategies can have formulated. There are different demographic variables which affect online shopping behavior of the customers (Zhou \& Wang, 2014). Previous research suggests that demographic variables have a different impact on online shopping behavior of the consumers. Demographic variables are the multitude of factors which have been used by the number of researchers to discriminate online shoppers from non-online shoppers. There are a number of studies which have confirmed a significant association of demographic variables with online shopping behavior (Brown et al., 2003). The research about internet shoppers includes demographic variables consisting of age, income and household income (Fram \& Grandy, 1995). Five basic demographic variables such as income, age, gender, education and occupation are good predictors of online shopping but their prediction power depends on product types (Naseri \& Elliot, 2011). Online shopping in India is significantly affected by demographic variables of the consumers (Richa, 2012). But, there are certain research which point out that demographic variable such as age, income and education have a modest impact on the decision whether to purchase online or not (Bellman, 1999; Modahl, 2000). More educated younger males with a high social status as compared to less educated, female and less wealthy people are using internet more for online purchasing (Akhter, 2003).

Age as one of the variables of the demographic factor does impact possession of internet and frequency of online purchase among consumers. Age influences the involvement level of the consumer (Jain \& Sharma, 2002) and different age groups have different attitudes towards online shopping. Young people are more risk takers in trying new technology. internet usage by young people is more compared to people from other age groups (Atkin et al., 1998; Nimitha Aboobaker, 2014). People in the age group of between 30-45 years are more interested in doing online shopping compared to 
other age groups (Kanchan et. al., 2015). Older online shoppers search for fewer products than young online shoppers but they purchase as much as younger consumers. Age explained more variance in purchasing behavior if the consumer had first searched for the product online (Sorce et al., 2005). Performance expectation, website features, gender, age (Khare et al., 2012) and social influence are the major drivers for online shopping among old consumers compared to young consumers (Lian \& Yen, 2014).

Gender is one of the demographic variables of the consumer which has been explored by the various researchers from different perspectives like risks of online shopping (Garbarino \& Strahilevitze, 2004), website design (Cyr \& Bonanni, 2005), acceptance of technology (Sanchez and Franco, 2006) and evaluate technology (Venkatesh 2002). Female's cognitive attitude towards online shopping is lower than Men. Men showed higher behavioral intention to shop online than females (Bassam Hasan, 2009). Gender and yearly income of the consumers have a significant impact on shopping habits of online shoppers (Verma \& Patel, 2017). Socioeconomic variables (age, gender, and income) do not impact the behavior of experienced online shoppers (Herna'ndez et al., 2011). Men's cognitive, affective and behavioral online shopping attitudes are higher than those of women (Dittmar et al., 2004; Hasan, 2009). Women's shopping orientation is different from Men. Women are more motivated by emotional, social interaction and perceive greater risk (Dillon et al., 2014) where as men are motivated by convenience interaction (Zhou et al., 2007) and perceive less risk (Dillon et al., 2014). Age and gender affect Indian consumer's online shopping attitudes (Khare et al., 2012). Davis et al. (2014) showed a different picture in this regard and they concluded that there is no online-gender effect on hedonic shopping motivation and purchase intentions.

Income of the consumers plays a crucial role in influencing consumer behavior. Family income and individual income determines the purchasing power of consumers (Hawkins et al., 2003). Occupation and education level of the consumers influence consumer preference and income facilitates the means to acquire the preferred products (Mulhern et al., 1998). Consumers' adoption of online shopping is positively related to income (Gong et al., 2013), household size, and innovativeness (Sultan \& Henrichs, 2000). Wealthier people use the internet for online transactions (Akhter, 2003). 
Marital status, gender, location, age, income and level of education are important predictors of online shopping for online shoppers (Kunz, 1997; Sultan \& Henrichs, 2000). The demographic characteristics of consumers such as marital status, education, age and gender were discussed by Gong et al. (2013); Davis et al. (2014); Khare et al. (2012); Hernández et al. (2011). Marital status and household have a strong moderation effect on online shopping (Brown \& Venkatesh, 2005).

Occupation is important in evaluating an individual's shopping behavior. Number of researchers have indicated the consumption of products is different as per the occupation of the consumers. Consumer involvement is different for consumers of different occupations but it is not strong in nature (Jain \& Sharma, 2002).

Education also plays an important role in understanding consumer behavior. There are number of studies that have confirmed that well educated consumers prefer online shopping (Sin \& Tse, 2002; Hui \& Wan, 2006). The level of education determines the understanding level of the person. Educated people are more towards online shopping and they perceived less security issues (Hui \& Wan, 2006). People with a higher educational background are more likely to purchase online (Bellman et al., 1999). Age, income, gender, and education levels are significantly correlated with web usage of consumers (Korgaonkar et al., 1999). Consumers having a good education background favor online shopping (Gong et al., 2013).

Attitude towards online shopping is defined as consumers feelings, either positive or negative, in relation to accomplishing the purchasing behavior on the internet (Chiu et al., 2005). As per previous research, attitude towards online shopping has a significant impact on online shopping behavior of shoppers (Lin, 2007).

These researchers have conducted their surveys in different countries and in different locations. It is important to analyze the affect of demographic variables on the online shopping behavior in India. This study is as per the Indian perspective. The current scenario has changed and now, the mindset of the consumers towards online shopping is also changing in India. Now, consumers have accepted this new mode of shopping and they have become habituated by it. It is important to examine the current mindset 
of the consumers towards online shopping. It is important to examine the demographic profile of the consumers and how it impacts the attitude of online shoppers towards online shopping in this current environment of online marketing.

\section{CONCEPTUAL FRAMEWORK AND RESEARCH HYPOTHESIS}

The basic need of marketing starts with the analysis of consumer behavior. "Consumer behavior is the study which explains the process involved when an individual selects, purchases, uses the products, ideas or services to satisfy needs and desires (Schiffman \&Kanuk, 2004)". It is essential to understand the concept of consumer behavior in relation to online shopping. As per the study "Analysis of consumer behavior online", conducted by Petrovic Dejan (2007), online shopping behavior is defined as the most appropriate behavioral appearances of online customers and explores product information. There are different consumer behavior theories that can guide the researchers to understand: How consumer behaviors are changing for online shopping? There are various established models which explain the various factors which affect consumer behaviors. The Theory of Reasoned Action (TRA) explains individual behavior which individual performs intentionally, and intention is a function of attitude towards the behavior (Ajzen \& Fishbein, 1980; Ajzen, 1985). The Technology Acceptance Model (TAM) describes the perceptions or beliefs about the innovation which are instrumental in the development of attitudes that will eventually result in system utilization behavior (Davis, 1989; Davis, Bagozzi \& Warshaw, 1992).

The present study focuses on determining the significance of demographic variables on online shopping in India. The online shopper's intentions are significantly affected by the perceived consequences of online shopping, consumer's attitude and social inluence (Khalifa \& Limayen, 2003). Online shopping intentions of rural farmers are also increasing in India which can be further enhanced by launching awareness camps (Jamaluddin, 2013). There is an important relationship that exist between internet purchasing intention and customers demographics (Akhter, 2003). Previous online shopping experience hasa significant positive influence on consumers 'online purchase intentions regardless of the product category 
and gender (Dai, 2007). Shopping frequency of online shoppers plays a moderating role on consumer intentions (Overby \& Lee, 2006). Frequency of being online or using the internet is positively related to online shopping (Donthu \& Garcia, 1999; Kolesar et al., 2000).

As per the above discussion, frequency of shopping online or frequency of being online is positively related to consumer's intention and consumers' intension is affected by the consumer's attitude towards online shopping. In this study, frequency of online purchasing represents the consumer's attitude towards online shopping. This paper takes a step forward to understand the association of demographic variables and consumer's attitude towards online shopping. The figure below represents the demographic variables under study.

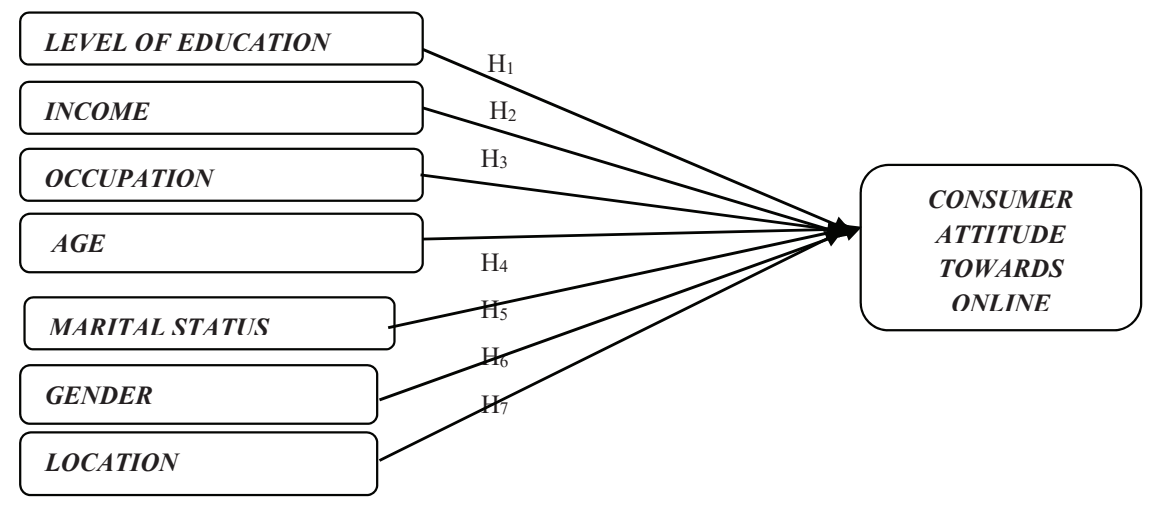

Figure 1: Proposed Conceptual Research Framework for Association of Demographic Variables with Online Shopping Behavior

\section{HYPOTHESES DEVELOPMENT}

As per above discussion hypotheses are formulated for this study

H1: There is a significant association between level of education of the consumers and the attitude of the online shoppers towards online shopping

H2: There is a significant association between income of the consumers and the attitude of the online shoppers towards online shopping 
H3: There is a significant association between occupation of the consumers and the attitude of the online shoppers towards online shopping

H4: There is a significant association between age of the consumers and the attitude of the online shoppers towards online shopping

H5: There is a significant association between marital status of the consumers and the attitude of the online shoppers towards online shopping

H6: There is a significant association between gender of the consumers and the attitude of the online shoppers towards online shopping

H7: There is a significant association between location of the consumers and the attitude of the online shoppers towards online shopping

\section{METHODOLOGY}

The current study used a survey research method in order to examine the role of demographic variables in affecting the attitude of online shoppers towards online shopping. Self-administered questionnaires were prepared for this study which included 7 demographic variables and questions related to internet usage and experience of online shopping of the online shoppers. This paper included a sample drawn from consumers who have experienced online shopping. In this study, data were collected from Delhi, Uttar Pradesh mainly from Gorakhpur, and Mumbai locations. Delhi and Mumbai are considered as metropolitan cities. In these cities, lives of the consumers are different compared to the other cities. Consumers from metropolitan cities are occupied with their busy life style and hectic work schedule. These cities have all kinds of brands in their local markets but, people have no time for doing shopping in the local markets or some people prefer to shop from home only by placing orders online. Gorakhpur is a non -metropolitan city. People have a less hectic work schedule and busy life style. Local markets have few brands only so if people want to buy certain brands then, they have to search for it in other markets or through the online mode only. In this study, an attempt was made to collect different kinds of responses from metropolitan and non-metropolitan cities. In this way, the sample can represent the Indian consumers' point of view for online shopping. Convenience sampling was employed for the distribution of the questionnaire to the respondents. Responses were collected through the 
offline mode. The researcher visited different colleges, malls and various places for collecting data in the given cities but out of experience, it was observed that people were interested in filling questionnaire in the evenings. So, data was collected from various places in the given cities during evenings. A total 582 questionnaires were collected from the respondents and out of that, only 542 questionnaires were selected for the study. These questionnaires were free from errors and completely filled. A descriptive analysis was initially performed to provide information pertaining to the demographics of the respondents. An associative analysis in the form of a chi-square analysis was conducted to test for association of the variables to the attitude of the shoppers towards online shopping. Later, hypothesis testing was subsequently conducted to determine whether the hypothesis proposed based upon a review from the existing literature were supported or otherwise. Lastly, implications of the results from the analysis are discussed and recommendations provided.

\section{DATA ANALYSIS}

\section{Descriptive Statistics}

This portion of the study is is related to verifying the main objectives of the study. The researcher used statistical tools like the chi-square for analysis of the primary data. A survey was conducted in New Delhi, Uttar Pradesh mainly from Gorakhpur and Mumbai by taking consideration of the fact that online shopping is still a metropolitan phenomenon in India.

As per Table 1, a total of $66.1 \%$ respondents were married and the rest were single. A total of $55.7 \%$ were male and the rest were female. Respondents in New Delhi were 34.9\%, Gorakhpur 32.1\% and Mumbai $33 \%$. A total $41.3 \%$ respondents belonged to the age category of $30-45$ years, $36.3 \%$ belonged to the age category of $18-30$ years, $14.9 \%$ respondents belonged to the age category of above 45 years and only $7.4 \%$ belonged to the age category of below 18 years. A total $45 \%$ respondents were graduates, $35.6 \%$ were post graduates, $13.5 \%$ were higher secondary school educated and rest belonged to other categories. A total $53.9 \%$ belonged to the income group of Rs. $20000-50000 ; 33.6 \%$ belonged to income group of less than 20,000 ". Only $10.9 \%$ belonged to the higher income group category (Rs. 
$50000-80000$ ) and rest belonged to the income category of above 80000 . The majority of the respondents were service persons, only $24.4 \%$ respondents belonged to business, $16.2 \%$ respondents were students, $3 \%$ respondents were housewives and rest belonged to other categories.

Table 1: Distribution of Respondents on the Basis of Demographic Variables

\section{Gender}

Female

Male

Age

Below 18

18-30

30-45

Above 45

Qualification

Higher Secondary

Graduation

Post Graduation

Others

Income

Less than 20,000

$20,000-50,000$

$50,000-80,000$

Above 80,000

Marital status

Single

Married

Location

New Delhi

Gorakhpur

Mumbai
184

240

302

40

197

224

81

73

244

193

32

182

292

59

9

358

189

174

179
$33.6 \%$

$53.9 \%$

$10.9 \%$

$1.7 \%$

$44.3 \%$

$55.7 \%$

$7.4 \%$

$36.3 \%$

$41.3 \%$

$14.9 \%$

$13.5 \%$

$45 \%$

$35.6 \%$

$5.9 \%$

$33.9 \%$

$66.1 \%$

$34.9 \%$

$32.1 \%$

$33 \%$ 


\begin{tabular}{lcc}
\hline \multicolumn{1}{c}{ Demographic Variables } & Frequency & Percentage \\
\hline Occupation & & \\
Service & 298 & $55 \%$ \\
Business & 132 & $24.4 \%$ \\
Students & 88 & $16.2 \%$ \\
Housewife & 16 & $3 \%$ \\
Others & 8 & $1.5 \%$ \\
Source: Primary data & &
\end{tabular}

\section{Frequency of Buying Online}

People use the internet for different purposes. In this study, $25.5 \%$ of the respondents used the internet mainly for online shopping. People preferred online shopping for saving time or to save from the complexities of the offline markets or for better price options. People have their mobile phone on their hands and from the phone, they can access different information with a single click. Online shopping is becoming a trend in India because it suits modern societies. The details of frequency of buying online are tabulated below in the Table 2 .

A total $54.8 \%$ of the respondents bought products online within three months, $20.1 \%$ consumers bought products online within a month, 20.3\% of the buyers bought products within six months and $4.8 \%$ of respondents bought products within a year. The majority of the respondents bought products online on a quarterly basis. Therefore, we can conclude that those who are doing online shopping like it and prefer to do online shopping within three months. As per the data the frequency of buying products online is higher for males compared to females. Males are do online shopping more compared to females. $29.7 \%$ males and $25.1 \%$ females as compared to the total number of the respondents prefer to do online shopping within three months. $11.4 \%$ males and $8.7 \%$ female prefer to do online shopping within a month. $11.9 \%$ males and $8.4 \%$ females like to do online shopping within six months. As per data the majority of the respondents (54.8\%) prefer to shop online within three months, which is a positive indication that people like to do online shopping and they are repeating it within three months. 
Table 2: Distribution of Respondents on the Basis of Frequency of Buying Products Online

\begin{tabular}{|c|c|c|c|c|}
\hline \multicolumn{4}{|c|}{ Gender of the Respondents } & \multirow{2}{*}{ Total } \\
\hline & Female & & Male & \\
\hline \multirow{12}{*}{$\begin{array}{l}\text { Frequency of buying } \\
\text { product online }\end{array}$} & At least once a month & 47 & 62 & 109 \\
\hline & & $43.1 \%$ & $56.9 \%$ & $100.0 \%$ \\
\hline & & $19.6 \%$ & $20.5 \%$ & $20.1 \%$ \\
\hline & Once in three months & 136 & 161 & 297 \\
\hline & & $45.8 \%$ & $54.2 \%$ & $100.0 \%$ \\
\hline & & $56.7 \%$ & $53.3 \%$ & $54.8 \%$ \\
\hline & Once in a six month & 45 & 65 & 110 \\
\hline & & $40.9 \%$ & $59.1 \%$ & $100.0 \%$ \\
\hline & & $18.8 \%$ & $21.5 \%$ & $20.3 \%$ \\
\hline & once a year & 12 & 14 & 26 \\
\hline & & $46.2 \%$ & $53.8 \%$ & $100.0 \%$ \\
\hline & & $5.0 \%$ & $4.6 \%$ & $4.8 \%$ \\
\hline
\end{tabular}

Source: Primary data

\section{Association between Customers Profile Variables and Online Shopping Behavior of the Customers}

The level of experience and frequency of online purchase represents the online shopping behavior of the consumer. For estimation of online shopping behavior of the consumer, the customers' frequency of buying products online was considered. The online shopping behavior may be be influenced by the socioeconomic psychological profile of the customers. For online shoppers, gender, marital status, residential location, age, education, and income are important predictors of internet purchasing (Sultan \& Henrichs, 2000; Mehta \& Sivadas, 1995; Kunz, 1997). In this study, the profile variables are age, gender, occupation, location, level of education, marital status and income of the consumer.

For finding an association between the profile of customers and their attitude towards online shopping, the chi-square was administered. The result of the chi-square statistics are presented in Table 3. Level of education and level of income of the respondents are the consumer's profile variables which are significantly associated with online shopping behavior of the consumer since the respective 'chi-square' statistics are significant at the $5 \%$ level of significance. 
Table 3: Association of Customer's Profile Variable and Online Shopping Behavior of Consumer

\begin{tabular}{llcc}
\hline S.No & \multicolumn{1}{c}{$\begin{array}{c}\text { Customers profile's } \\
\text { variable }\end{array}$} & $\begin{array}{c}\text { Chi-square } \\
\text { (p-value) }\end{array}$ & Result \\
\hline 1. & Education & 0.03 & Significant \\
2. & Income per month & 0.01 & Significant \\
3. & Occupation & 0.493 & Not significant \\
4. & Age & 0.194 & Not Significant \\
5. & Marital status & 0.07 & Not significant \\
6. & Gender & 0.831 & Not significant \\
7. & Location & 0.06 & Not Significant \\
\hline
\end{tabular}

There is a positive association between level of education and level of income of the respondents with online shopping behavior of the consumers. As per Table 4 and Table 5, there is a weak positive association between these variables and online shopping behavior. It indicates that there is a significant association among the customers under different above said variables regarding their online shopping behavior. A higher level of education and a higher level of income means that the higher will be the chance that the shopper will shop online compared to others.

Table 4: Phi - Cramer's V for Level of Education

\begin{tabular}{llcc}
\hline & & Value & Approx. Sig. \\
\hline Nominal by & Phi & .183 & .033 \\
Nominal & Cramer's V & .106 & .033 \\
\hline N of Valid Cases & & 542 & \\
\hline
\end{tabular}

Table 5: Phi-Cramer's V for Level of income

\begin{tabular}{lccc}
\hline & & Value & Approx. Sig. \\
\hline Nominal by & Phi & .331 & .000 \\
Nominal & Cramer's V & .191 & .000 \\
\hline N of Valid Cases & & 542 & \\
\hline
\end{tabular}




\section{CONCLUSION}

This study tried to understand the characteristics of online shoppers and the role of demographic variables of online shoppers in influencing online buying behavior of shoppers India. A flexible attribute of internet makes online shopping available all the time to the consumers. This paper has examined the relationship between demographic variables and attitude of online shoppers towards online shopping. This study proposes seven hypotheses which are diagramed in Figure 1. Out of seven hypotheses, only two alternative hypotheses are accepted on the basis of p-value of Chi-square test. Results showed that only two variables are significantly associated with the attitude of the shoppers towards online shopping. Level of education and level of income have a significant association with the attitude of online shoppers towards online shopping. These two variables are positively associated with the attitude of the online shoppers. The result of this study seems to be consistent with the study of Sultan and Henrichs (2000) and Hairong Li et al. (2006), and not consistent with the study in which education and income of the shoppers have no significant impact on online shopping behavior (Richa, 2012). This study found that some variables (age, gender, marital status, occupation and location) of online shoppers have no significant association with the attitude of the shoppers towards online shopping and in the case of age: this result seems consistent with the study of Richa (2012); Hairong Li et al. (2006); In terms of gender of the shoppers the result seems consistent with the study of Richa (2012); Hairong Li et al. (2006); Lian and Yen (2014), and not consistent with the study of Kalia (2017); In terms of occupation the results seems consistent with the study of Nagra and Gopal (2013) and not consistent with the study of Kalia (2017). This study concluded that highly educated and high income earning internet users are positively associated with the frequency of buying online. Educated online shoppers favor online shopping more as compared to others. High education level and high income earning online shoppers are more frequent in doing online shopping as they have proper internet knowledge for conducting online shopping/online browsing and these shoppers can take risk for doing online shopping as this risk is backed by their high income.

The current findings significantly enhance the understanding of user acceptance of online shopping. Consideration of these two variable 
(level of education and level of income) identified should lead to more successful adoption of online shopping. The findings of the influence of demographic variables on online shopping behavior of the shoppers have several implications. E-commerce firms should utilize these parameters in formulating the mix of online marketing for convincing online shoppers. Online retailers can use the results as this paper investigated the association of different demographic variables with the attitude towards online shopping. Online retailers or websites should pay attention towards 'education and income' demographic variable of the shoppers in the process of formulating strategies to attract more consumers towards their portals. Online portals should add elements which can grab attention of different online shoppers having various levels of education and income.

Future research can further evaluate and analyze the effect of demographic variables on the attitude of online shoppers from a larger perspective by including responses from more locations of India. In this paper both metropolitan cities and non-metropolitan city were considered for the study. But, the majority of the population of India are living in rural areas so researchers should include the rural areas of India for getting better insights on the topic. There are other variables other than the demographic variables which can have an impact on the attitude of shoppers towards online shopping. Researchers can also examine the impact of these variables on online shopping behavior of the shoppers in India.

\section{REFERENCE}

Aboobaker, N. (2014). Online purchase behavior among youth in India. International Journal of Scientific Research, 3(9), 505-507.

Ajzen, I. (1985). From intentions to actions: A theory of planned behavior. In Kuhl, J. \& Beckman, J. (Eds.), Action-Control: From cognition to behavior (11-39). Heidelberg, Germany: Springer.

Ajzen, I., \& Fishbein, M. (1980). Understanding attitudes and predicting social behavior. Englewood Cliffs, NJ: Prentice-Hall.

Akhter, S. (2003). Digital divide and purchase intention: Why demographic psychology matters. Journal of Economic Psychology, 24(3), 321-327. 
Atkin, D. J., Jeffres, L. W., \& Neuendorf, K. A. (1998). Understanding Internet adoption as telecommunications behavior. Journal of Broadcasting \& Electronic Media, 42(4), 475-490.

Bellman, S., Lohse, G. \& Johnson, E. (1999). Predictors of online buying behaviour. Communications of the ACM, 42(12), 32-38.

Brown, M., Pope, N., \& Voges, K. (2003). Buying or browsing? An exploration of shopping orientations and online purchase intention. European Journal of Marketing, 37(11/12), 1666-1684.

Brown, S. A. \& Venkatesh, V. (2005). Model of adoption of technology in household: A baseline model test and extension incorporating household life cycle. MIS Quarterly, 29(3), 399-426.

Chen, M. C., Cheu, A. L., \& Chang, H. H. (2005). Mining changes in customer behavior in retail marketing. Experts Systems and Application, 28(4), 773-781.

Chiu, Y. B., Lin, C. P., \& Tang, L. L. (2005). Gender differs: assessing a model of online purchase intentions in e-tail service. International Journal of Service Industry Management, 16(5), 416-435.

Dai, B. (2007). The impact of online shopping experience on risk perceptions and online purchase intentions: the moderating role of product category and gender (Doctoral dissertation).

Davis, F. D. (1989). Perceived usefulness, perceived ease of use and user acceptance of information technology. MIS Quarterly, 13(3), 319-339.

Davis, F. D., \& Warshaw, P. R. (1992). Extrinsic and Intrinsic Motivation to use computers in the workplace. Journal of Applied Social Psychology, 22(14), 1111-1132.

Davis, R., Lang, B., \& San Diego, J. (2014). How gender affects the relationship between hedonic shopping motivation and purchase intentions?. Journal of Consumer Behaviour, 13(1), 18-30. 
Dillon, S., Buchanan, J., \& Al-Otaibi, K. (2014). Perceived risk and online shopping intention: A study across gender and product type. International Journal of E-Business Research (IJEBR), 10(4), 17-38.

Dittmar, H., Long K., Meek, R. (2004). Buying on the internet: Gender difference in online and conventional buying motivation. Sex Roles, 50(5-6), 423-444.

Donthu, N., \& Garcia, A. (1999). The internet shopper. Journal of Advertising Research, 39(3), 52-58.

Fram, E. H., \& Grandy, D. B. (1995). Internet buyers: Will the surfers become buyers?. Direct Marketing, 58(6), 63-65.

Glassberg, B. C., Grover, V., and Teng J.T.C. (2006). Information system research with an attitude. ACM SIGMIS Database: The Data Base for Advances in Information Systems, 37(2-3), 76-85.

Gong, W., Stump, R. L., \& Maddox, L. M. (2013). Factors influencing consumers' online shopping in China. Journal of Asia Business Studies, 7(3), 214-230.

Hasan, B. (2010). Exploring gender differences in online shopping attitude. Computers in Human Behavior, 26(4), 597-601.

Hawkins, I. D., Best, J. R., \& Coney, A. K. (2003). Consumer behaviour Building marketing strategy (9th ed.). New Delhi: Tata McGraw Hill.

Hernández, B. Jiménez, J., \& Martín, J. (2011). Age, gender and income: Do they really moderate online shopping behavior? Online Information Review, 35(1), 113-133.

Hui, T. K., \& Wan, D. (2006). Factors affecting Internet shopping behaviour in Singapore: Gender and educational issues. International Journal of Consumer Studies, 31(3), 310-316.

IAMAI \& IMRB (2016). Internet in India. Retrieved from http://docplayer. net/48920096-Internet-in-india-an-iamai-kantar-imrb-report.html, accessed on 10/02/2018. 
India Brand Equity Foundation. (2019). Indian E-commerce Industry Analysis. Retrieved from https://www.ibef.org/industry/ecommercepresentation

Jain, S. K., \& Sharma, K. (2002). Relevance of personal factors as antecedents of consumer involvement: An exploration. Vision, 6(1), $13-24$.

Kalia, P. (2017). Does demographics affect purchase frequency in online retail?. International Journal of Online Marketing, 7, 42-56.

Kanchan, U., Kumar, N., \& Gupta, A. (2015). A study of online purchase behavior of customers in India. ICTACT Journal on Management Studies, 1(3), 136-142.

Karayanni, D. (2003). Web-shoppers and non-shoppers: Compatibility, relative advantage and demographics. European Business Review, 15, 141-152.

Khalifa, M. \& Limayem, M. (2003). Drivers of internet shopping. Communications of the ACM, 46(12), 233-239.

Khare, A., Khare, A., \& Singh, S. (2012). Attracting shoppers to shop online - Challenges and opportunities for the Indian retail sector. Journal of Internet Commerce, 11(2), 161-185.

Kolesar, M. B. \& Galbraith, R. W. (2000). A services-marketing perspective on e-retailing: Implications for e-retailers and directions for further research. Internet Research: Electronic Networking Application and Policy, 10(5), 424-438.

Korgaonkar, P. K. \& Wolin, L. D. (1999). A multivariate analysis of web usage. Journal of Advertising Research, 39(2), 53-68.

Kramer, M. (2012). The unraveling of apparel: Online shopping behavior. Reinvention: A Journal of Undergraduate Research, 5(1). 
Kunz, M. B. (1997). Online customers: Identifying store, product and consumer attitude which influences shopping on the Internet. (Published Doctoral dissertation). The University of Tennessee, Knoxville.

Li, H., Kuo, C., \& Rusell, M. G. (2006). The impact of perceived channel utilities, shopping orientations, and demographics on the consumer's online buying behavior. Journal of Computer Mediated Communication, $5(2)$.

Lian, J. W., \& Yen, D. C. (2014). Online shopping drivers and barriers for older adults: Age and gender differences. Computers in Human Behavior, 37, 133-143.

Liao, Z. \& Cheung, M. T. (2001). Internet based e-shopping and consumer attitudes: An empirical study. Information and Management, 38(5), 299-306.

Lin, H. F. (2007). Predicting consumer intensions to shop online: An empirical test of competing theories. Electronic Commerce Research and Applications, 6(4), 433-442.

Mehta, R., \& Sivadas, E. (1995). Direct marketing on the internet: An empirical assessment of consumer attitudes. Journal of Direct Marketing, 9(3), 21-32.

Modahl, M. (2000). Now or never: How companies must change to win the battle for the internet consumer. New York: Harper Business.

Mulhern, F. J., Williams, J. D., \& Leone, R. P. (1998). Variability of brand price elasticities across retail stores. Journal of Retailing, 74(3), $427-445$.

Nagra, G., \& Gopal, R. (2013). A study of factors affecting on online shopping behavior of consumers. International Journal of Scientific and Research Publications, 3(6), 1-4.

Naseri, M. \& Elliott, G. (2011). Role of demographics, social connectedness and prior internet experience in adoption of online shopping: Application 
for direct marketing. Journal of Targeting, Measurement and Analysis for Marketing, 19(2), 69-84.

Nielsen. (2014). Global online purchase intentions have doubled since 2011 for E-books, toys, sporting goods; online market for pet and baby supplies, other consumable products also growing. Retrieved from http:/www.nielsen.com/ug/en/press-room/2014/global-onlinepurchase-intentions-have-doubled-since-2011-for-ebooks-toyssporting-goods.html

Overby, J. W., \& Lee, E. J. (2006). The effects of utilitarian and hedonic online shopping value on consumer preference and intentions. Journal of Business Research, 59(10-11), 1160-1166.

Petrovic Dejan. (2007). Analysis of consumer behavior online. analogik. com.

Phang, C. W., Kankanhalli, A., Ramakrishnan, K., \& Raman, K. S. (2010). Customers preference of online store visit strategies: An investigation of demographic variables. European Journal of Information Systems, 19(3), 344-358.

Richa, D. H. (2012). Impact of demographic factors of consumers on online shopping behaviour: A study of consumers in India. International Journal of Engineering and Management Science, 3(1),43-52.

Schiffman, L. G. \& Kanuk, L. L. (2004). Consumer behavior. Upper Saddle River, NJ: Prentice Hall, 8e.

Sorce, P., Perotti, V. \& Widrick, S. (2005). Attitude and age differences in online buying. International Journal of Retail \& Distribution Management, 33(2), 122-132.

Sultan, F., \& Henrichs, R. B. (2000). Consumer preferences for Internet services over time: Initial explorations. The Journal of Consumer Marketing, 17(5), 386-402. 
Verma, S., \& Patel, K. (2017, April). Association between shopping habit and demographics of m-commerce user's in India using two way ANOVA. In 2017 2nd International Conference for Convergence in Technology (I2CT) (pp. 38-43). IEEE.

Zahedi, F. M., \& Song, J. (2009). Do websites change customers' beliefs? A study of belief prior-posterior beliefs in e-commerce. Information \& Management, 46(2), 125-137.

Zhou, I., Dai, L., \& Zhang, D. (2007). Online shopping acceptance model - A critical survey of consumer factors in online shopping. Journal of Electronic Commerce Research, 8(1), 41-62.

Zhou, Y., \& Wang, X. C. (2014). Explore the relationship between online shopping and shopping trips: An analysis with the 2009 NHTS data. Transportation Research Part A-Policy and Practice, 70, 1-9. 


\section{APPENDIX}

\section{QUESTIONNAIRE}

\section{Section - I (Respondent's profile)}

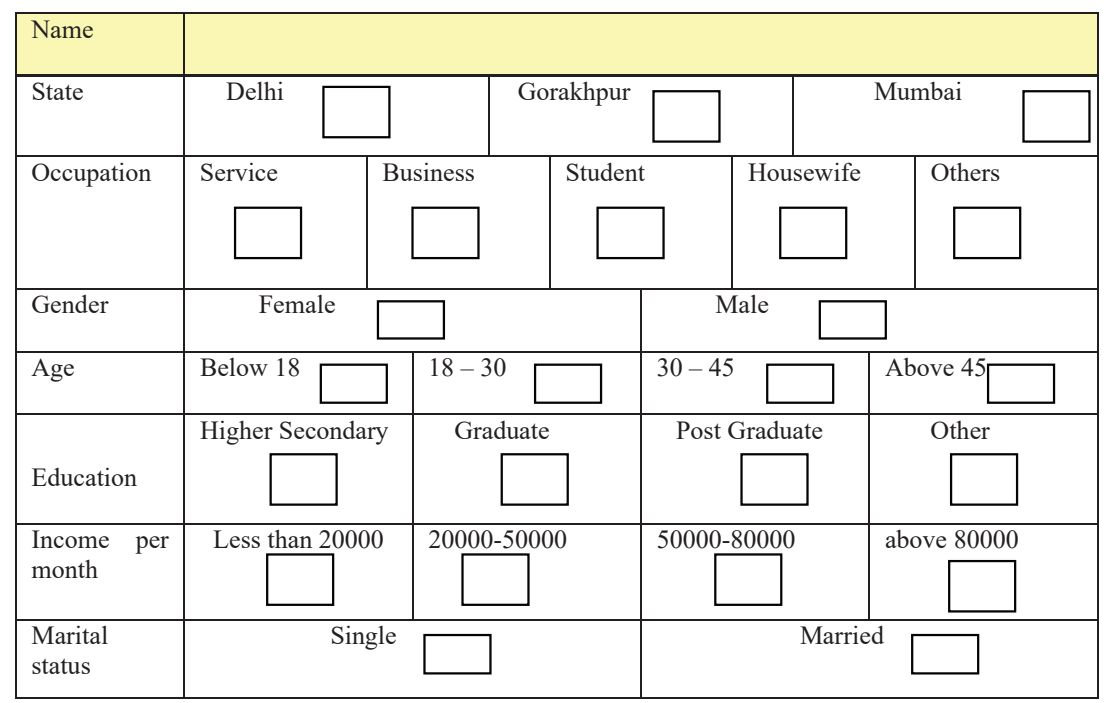

\section{Section II}

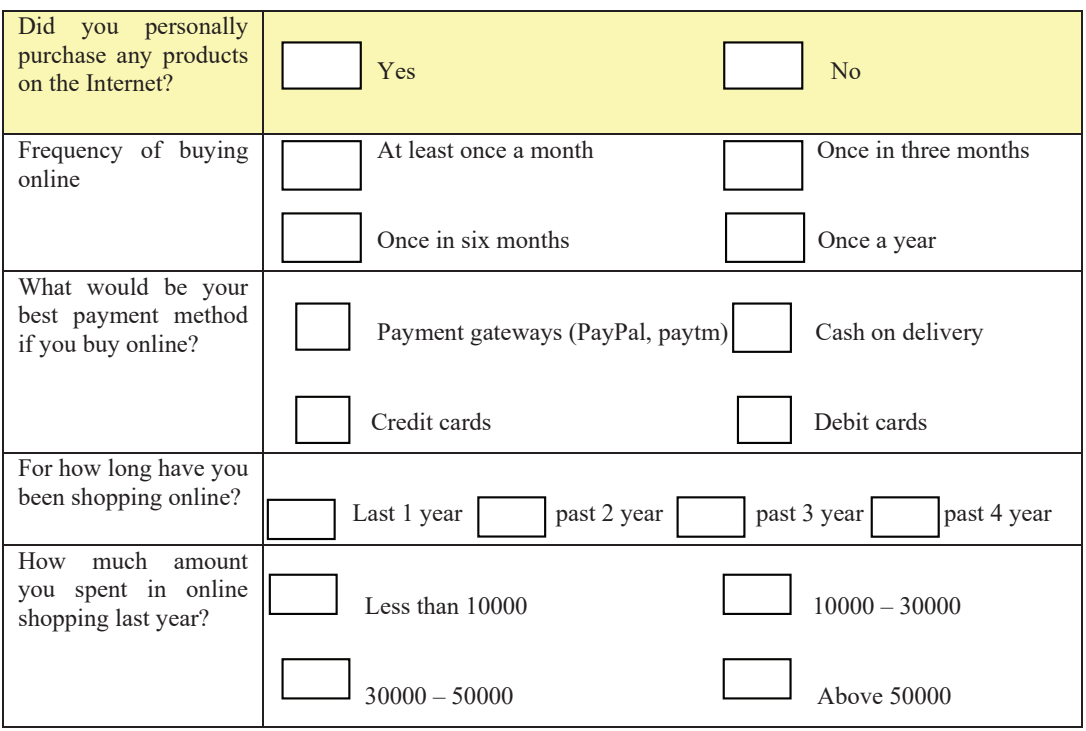

